\title{
Comparison between indirect enzyme-linked immunosorbent assays for Anaplasma marginale antibodies with recombinant major surface protein 5 and initial body antigens
}

\author{
Virgínia M G Silva*, Flábio R Araújo, Claudio R Madruga/ ${ }^{+}$, Cleber 0 Soares, \\ Raul H Kessler, Maria AO Almeida**, Stênio P Fragoso***, Lenita R Santos*, \\ Carlos AN Ramos, Gisele Bacanelli, Roberto AA Torres Júnior
}

\begin{abstract}
Embrapa Gado de Corte, Caixa Postal 154, 79002-970 Campo Grande, MS, Brasil *Pós-Graduação em Imunologia, Instituto de Ciências da Saúde **Departamento de Patologia e Clínicas, Escola de Medicina Veterinária, Universidade Federal da Bahia, Salvador, BA, Brasil ***Instituto de Biologia Molecular do Paraná, Curitiba, PR, Brasil
\end{abstract}

\begin{abstract}
Indirect enzyme-linked immunosorbent assays (ELISAs) based on recombinant major surface protein 5 ( $r M S P 5)$ and initial body (IB) antigens from a Brazilian isolate of Anaplasma marginale were developed to detect antibodies against this rickettsia in cattle. Both tests showed the same sensitivity (98.2\%) and specificities (100\% for rMSP5 and $93.8 \%$ for IB ELISA) which did not differ statistically. No cross-reactions were detected with Babesia bigemina antibodies, but 5 (rMSP5 ELISA) to 15\% (IB ELISA) of cross-reactions were detected with B. bovis antibodies. However, such difference was not statistically significant. Prevalences of seropositive crossbred beef cattle raised extensively in Miranda county, state of Mato Grosso do Sul, Brazil, were $78.1 \%$ by rMSP5 ELISA and $79.7 \%$ by IB ELISA. In the analysis of sera from dairy calves naturally-infected with A. marginale, the dynamics of antibody production was very similar between both tests, with maternal antibodies reaching the lowest levels at 15-30 days, followed by an increase in the mean optical densities in both ELISAs, suggesting the development of active immunity against A. marginale. Results showed that all calves were seropositive by one-year old, characterizing a situation of enzootic stability. The similar performances of the ELISAs suggest that both tests can be used in epidemiological surveys for detection of antibodies to $\mathrm{A}$. marginale in cattle.
\end{abstract}

Key words: Anaplasma marginale - enzyme-linked immunosorbent assay - major surface protein 5 - initial body - Brazil

Anaplasmosis is an important vector-borne hemoparasitic rickettsial disease of ruminant livestock in tropical and subtropical regions of the world (Palmer et al. 1986), including South America (Barros et al. 2005). The disease is caused by Anaplasma marginale, an ehrlichial pathogen of the genogroup II (Dumler et al. 2001), and is characterized by fever, anemia, general weakness, pallor mucous membranes, weight loss (Ajayi et al. 1978), abortion (Correa et al. 1978), decreased milk production, and mortality during the acute phase of infection (Palmer et al. 1986).

Control of $A$. marginale infection requires both an effective vaccine and accurate identification of carrier cattle (Andrade et al. 2004). Two possible methods for routine carrier detection are identification of rickettsial DNA in blood and the detection of A. marginale-specific antibodies in serum (McGuire et al. 1991, Knowles et al. 1996). Despite the high sensitivity and specificity of the former ones, serological methods remain the most wildly used diagnostic tools.

\footnotetext{
Financial support: Fundect, $\mathrm{CNPq}$

+Corresponding author: madruga@cnpgc.embrapa.br

Received 25 November 2005

Accepted 26 May 2006
}

Serologic tests for anaplasmosis based on crude antigen have a high error rate due to false-positive results with bovine erythrocyte proteins contaminating the $A$. marginale antigen and reacting with anti-erythrocyte antibodies in bovine sera (as reviewed by Knowles et al. 1996).

To improve serological diagnosis of bovine anaplasmosis, research has focused on the identification and characterization of A. marginale membrane antigens, by gene cloning and production of recombinant proteins, which would be suitable for diagnostic tests (Reyna-Bello et al. 1998). Six major surface proteins (MSPs) have been initially described: MSP1a, MSP1b, MSP2, MSP3, MSP4, and MSP5 (Palmer et al. 1986, Oberle et al. 1988, Visser et al. 1992). Recently, four new membrane proteins were identified: Ana29, Ana 32, Ana 37, and Ana 43 (Riding et al. 2003). From these, the immunodominant 19-kDa MSP5 has potential use in serological tests (Ndung'u et al. 1995, Knowles et al. 1996, Reyna-Bello et al. 1998, Torioni de Echaide 1998), as it is conserved between Anaplasma species and isolates, including Brazilian isolates of $A$. marginale (Visser et al. 1992, Kano et al. 2002, Oliveira et al. 2003)

In this study, we have compared recombinant MSP5 and initial body proteins as ELISA antigens for Anaplasma antibodies in Brazil.

\section{MATERIALS AND METHODS}

A. marginale isolate - Initial bodies (IB) were isolated from erythrocytes from a splenectomized calf experimen- 
tally infected with a Brazilian strain of A. marginale (Pernambuco, Zona da Mata). Blood was collected in vacuum tubes with heparin when rickettsemia reached $87 \%$.

Purification of IB - A. marginale IB were isolated from infected erythrocytes by differential centrifugation, as described by Palmer and McGuire (1984). Purification was certified by comparison in the sodium dodecyl sulfatepolyacrylamide gel electrophoresis (SDS-PAGE) with noninfected bovine erythrocytes. Western blots with monoclonal antibodies (MoAbs) ANAF16C1 and ANA22B1, to MSP5 and MSP1a, respectively (Visser et al. 1992, Palmer et al. 1988), were also performed, as described elsewhere (Oliveira et al. 2003).

Genomic DNA extraction - DNA was purified from $300 \mu 1$ of infected blood by Easy DNA kit (Invitrogen, US). The concentration of extracted DNA and the A260/ A280 ratio were determined on a GeneQuant spectrophotometer (Amersham Pharmacia Biotech, US).

Amplification of msp5 - Primers were designed to amplify a $714 \mathrm{bp}$ fragment, including the entire $m s p 5$ gene and a 3' UTR fragment, according to the reported msp5 nucleotide sequence (Genbank accession no. M93392). These primers were msp5F (5'-ATGAGAATTTTCAA GATTGTGTCTAACCTT-3') and msp5R (5'-AGGAAAG CCCCCAAAGCCCCATACTT-3'). PCR amplification reaction mixture was prepared in a volume of $50 \mu \mathrm{l}$, containing $10 \mathrm{mM}$ Tris- $\mathrm{HCl}$ (pH 8.5), $50 \mathrm{mM} \mathrm{KCl}, 1.5 \mathrm{mM} \mathrm{MgCl}_{2}, 0.2$ $\mathrm{mM}$ (each) deoxynucleoside triphosphate, $100 \mathrm{\eta g}$ (each) primer, $100 \eta \mathrm{g}$ of genomic DNA, and $2.5 \mathrm{U}$ of Taq DNA polymerase (Cenbiot, Brazil). Amplification was performed in a PTC-200 thermocycler (MJ Research, US) as follows: $94^{\circ} \mathrm{C}$ for $1 \mathrm{~min}$ (denaturation); the next 35 cycles were $94^{\circ} \mathrm{C}$ for $1 \mathrm{~min}$ (denaturation), $60^{\circ} \mathrm{C}$ for $1 \mathrm{~min}$ (annealing), and $72^{\circ} \mathrm{C}$ for $30 \mathrm{sec}$ (extension), and the last cycle was $72^{\circ} \mathrm{C}$ for $7 \mathrm{~min}$ (extension). PCR products were analyzed by electrophoresis in $1 \%$ agarose gel, stained with ethidium bromide $(0.5 \mathrm{mg} / \mathrm{ml})$.

Cloning of msp5 - PCR amplicon was cloned in plasmid $p$ TrcHisTOPO (Invitrogen), according to the manufacturer's instructions. The recombinant plasmid was used to transform Escherichia coli TOP10 cells. Insert orientation was determined by colony PCR, using plasmid primer Xpress (Invitrogen) and primer msp5R. The insert was also sequenced in both directions by the dideoxide method and analyzed in an ABI 3100 automatic sequencer (Applied Byosystems, US). Only sequences with a PHRED index greater than 20 were considered.

Recombinant MSP5 production - An overnight $50 \mathrm{ml}$ culture of $E$. coli TOP10 carrying the recombinant plasmid grown in liquid selective Luria-Bertani (LB) medium containing $100 \mu \mathrm{g} / \mathrm{ml}$ of ampicillin (LB-amp) was cultured in $450 \mathrm{ml}$ of LB-amp for $1 \mathrm{~h}$ at $37^{\circ} \mathrm{C}$. Isopropyl- $\beta$-Dthiogalactopyranoside (IPTG) was added at a final concentration of $1 \mathrm{mM}$. The cultures were allowed to grow for $6 \mathrm{~h}$. Aliquots of $2 \mathrm{ml}$ were taken before induction with IPTG and then every $2 \mathrm{~h}$. These aliquots were centrifuged at $18,000 \times \mathrm{g}$ and the pellet was frozen at $-20^{\circ} \mathrm{C}$. After $6 \mathrm{~h}$ culture, $E$. coli cells were recovered by centrifugation at $10,000 \times \mathrm{g}$ for $10 \mathrm{~min}$. The pellet was suspended in $20 \mathrm{ml}$ of $50 \mathrm{mM}$ phosphate buffer and then frozen in liquid nitrogen. After thawing at $4^{\circ} \mathrm{C}$, the suspension was sonicated (Sonifier 250 , Branson, US - output 40) for $6 \times 20$ s on ice. The recombinant protein production was verified by SDSPAGE, followed by Coomassie blue staining. The identity of rMSP5 was confirmed by Western blot with monoclonal antibody ANAF16C1, as described elsewhere (Oliveira et al. 2003).

Purification of MSP5 - The cell lysate was homogenized with $30 \mathrm{ml}$ of $50 \mathrm{mM}$ phosphate buffer and $50 \mathrm{ml}$ of $2 \times$ SDS-PAGE sample buffer. The material was boiled for $5 \mathrm{~min}$ and submitted to electrophoresis in a $2 \mathrm{~mm}$ preparative 15\% SDS-polyacrilamide gel (Hoeffer 600). After the protein separation, the gel was immersed on cold $1 \mathrm{M}$ potassium acetate (Neophytou et al. 1996). The major protein band was gel excised and electro dialyzed in glycine buffer at $35 \mathrm{~mA}$, for $3 \mathrm{~h}$, at $4^{\circ} \mathrm{C}$. The protein was dialyzed overnight against $5 \mathrm{M}$ urea, $1 \mathrm{mM}$ tris- $\mathrm{HCl}, \mathrm{pH} 7.7$, and $1 \%$ 2-mercaptoethanol, at $35 \mathrm{~mA}$ for SDS removal (Tuszynski \& Warren 1975), and dialyzed overnight against $50 \mathrm{mM}$ phosphate buffer, at $4^{\circ} \mathrm{C}$, for urea removal. Purity of the recombinant protein was assessed by SDS-PAGE.

ELISA standardization - optimal dilutions of antigen, sera and conjugate for ELISAs with rMSP5 and with IB were determined by testing 16 sera negative for $A$. marginale antibodies, from cattle kept in an isolation area of Embrapa Beef Cattle Research Center, and 16 sera positive for A. marginale antibodies, from experimentally-infected cattle.

ELISA with IB antigen - 96-well plates (ref. 3590, Costar, US) were adsorbed with $350 \mathrm{\eta g} / \mathrm{well}$ of IB proteins, diluted in adsorption buffer $\left(1 \mathrm{M} \mathrm{Na} \mathrm{NPO}_{4} \cdot 2 \mathrm{H}_{2} \mathrm{O}, 0.8 \mathrm{M}\right.$ $\mathrm{C}_{6} \mathrm{H}_{6} \mathrm{O}_{7} \cdot \mathrm{H} 2 \mathrm{O}, \mathrm{pH} 4.0$ ), for $12 \mathrm{~h}$, at $4^{\circ} \mathrm{C}$. Plates were then kept at $-20^{\circ} \mathrm{C}$. After thawing, the plates were washed five times with phosphate-buffered saline (PBS) with $0.1 \%$ tween (PBST) and were blocked with Dulbelcco's buffered saline, $\mathrm{pH} 7.2$, with $2 \% \gamma$-globulin free equine serum and $5 \%$ slim milk, for $4 \mathrm{~h}$, at $4^{\circ} \mathrm{C}$. After five washes with PBST, positive and negative sera (in quadruplicate) and test sera (in duplicate), diluted 1:1,000 in PBST, were incubated for $30 \mathrm{~min}$ at $37^{\circ} \mathrm{C}$. Plates were then washed five times with PBST, and $100 \mu \mathrm{l} /$ well of rabbit anti-bovine IgG horseradish peroxidase conjugate (ref. A-7414, Sigma, US), diluted 1:5000 in PBST, were added. The plates were incubated as described and after 10 washes with PBST, the chromogen/substrate $o$-phenylene diamine dihydrochloride (OPD; Sigma)/ $\mathrm{H}_{2} \mathrm{O}_{2}$ was added. The reaction was stopped by addition of $\mathrm{H}_{2} \mathrm{SO}_{4}(2.5 \mathrm{~N})$ and results were read on an El x 800 ELISA reader (Bio-Tek, US), with a filter of 490 ๆm.

ELISA with rMSP5 - 96-well plates (ref. 3590, Costar) were adsorbed with $3 \eta \mathrm{g} /$ well of rMSP5, diluted in Dulbelcco's phosphate buffer, $\mathrm{pH} 7.2$, for $12 \mathrm{~h}$, at $4^{\circ} \mathrm{C}$. Plates were then kept at $-20^{\circ} \mathrm{C}$. After thawing, plates were blocked with PBST with $2 \% \gamma$-globulin free equine serum and $5 \%$ slim milk, for $30 \mathrm{~min}$, at $37^{\circ} \mathrm{C}$. After five washes with PBST, positive and negative sera (in quadruplicate) 
and test sera (in duplicate), diluted 1:50 in PBST, were incubated for $40 \mathrm{~min}$ at $37^{\circ} \mathrm{C}$. Plates were then washed five times with PBST, and $100 \mu \mathrm{l} /$ well of rabbit anti-bovine IgG horseradish peroxidase conjugate (ref. A-7414, Sigma), diluted 1:10,000 in PBST, were added. Plates were incubated for $30 \mathrm{~min}$ at $37^{\circ} \mathrm{C}$ and after 10 washes with PBST, the chromogen/substrate substrate $o$-phenylene diamine dihydrochloride (OPD; Sigma)/ $\mathrm{H}_{2} \mathrm{O}_{2}$ was added. The reaction was stopped by addition of $\mathrm{H}_{2} \mathrm{SO}_{4}(2,5 \mathrm{~N})$ and results were read on a ELx-800 ELISA reader (Bio-Tek), with a $490 \eta m$ filter.

Cut-off determination - Cut-offs were determined as the mean optical density (OD) of 20 negative control sera plus three standard deviations.

Determination of sensitivity and specificity of the tests - Sensitivity of both tests was determined with 57 cattle sera positive for $A$. marginale antibodies by immunofluorescent antibody test (IFAT). Specificity was determined with 65 cattle sera negative for $A$. marginale antibodies by IFAT.

Cross-reactions with Babesia antibodies - Cross-reactions with Babesia antibodies were evaluated in 20 cattle sera positive for $B$. bovis or B. bigemina antibodies and negative for $A$. marginale antibodies by IFAT.

Prevalence of A. marginale in cattle raised extensively in Mato Grosso do Sul - Sera were collected from 128 cross-bred cows (predominantly Nelore) of a transition area between Brazilian Savanna and Pantanal regions, in the county of Miranda, Mato Grosso do Sul, according to the statistical model of the Centro Pan-Americano de Zoonoses (1979), that considered $95 \%$ of confidence degree and $2 \%$ of error probability. Cattle were raised extensively and ticks were not controlled in these farms, due to the low infestations in beef cattle. Sera from these calves were analyzed by both ELISAs for prevalence determination and comparison.

Evaluation of the ELISAs with sera from calves naturally infected with A. marginale - Sera from 28 Holstein calves from a dairy farm, located on an endemic region for anaplasmosis (São Pedro county, São Paulo, Brazil) were collected from 15 days up to one year of age and analyzed by IB ELISA and rMSP5 ELISA. After birth, these calves remained with their mothers for $24 \mathrm{~h}$, and then were kept in individual stalls until they reached four months. In the individual stalls, calves received four liters of colostrum for two days and then four liters of milk and ration ad libitum. After four months, calves were kept in collective pastures, where they were fed with silage, hay and ration.

Statistical analysis - Data were analyzed by Qui-square test or Fischer's exact test, with a confidence interval of $95 \%$.

\section{RESULTS}

$I B$ antigen production - The IB were partially purified from infected erythrocytes. In the SDS-PAGE analysis, four erythrocyte bands were detected in the IB antigen (data not shown). In the Western blot, monoclonal anti- bodies ANAF16C1 (MSP5) and ANA22B1 (MSP1a) reacted with epitopes of $16 \mathrm{kDa}$ and $80 \mathrm{kDa}$, respectively (Fig. 1).

Amplification and cloning of msp5 - As expected, a $714 \mathrm{bp}$ fragment was amplified with primers msp5F and msp5R, which was successfully cloned in $p$ TrcHis-TOPO. It was possible to sequence a $633 \mathrm{bp}$ fragment of the insert, which corresponds to the coding sequence of MSP5. The resulting DNA sequence (Genbank accession no. AY245428) showed $98.4 \%$ of identity (623/633 nucleotides) with msp5 from A. marginale Florida isolate (Genbank accession no. M93392) in the BLASTn analysis. At the protein level, the similarity between isolates was $99 \%$.

Expression of rMSP5 - A $22 \mathrm{kDa}$ protein was expressed (Fig. 2), which reacted with MoAb ANAF16C1 in the Western blot with cell lysate (Fig. 3). No reaction was detected with non-induced transformed TOP10 cells.

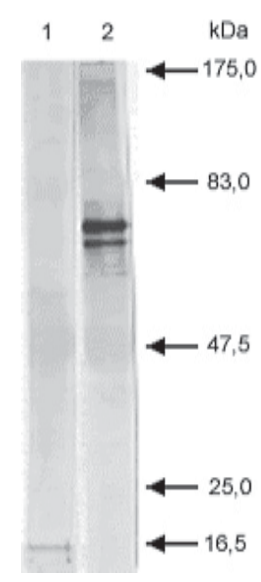

Fig. 1: Western blot of purified initial bodies from a Brazilian isolate (Pernambuco - Zona da Mata) of Anaplasma marginale and monoclonal antibodies (MoAb) ANAF16C1 (anti-MSP5) and ANA22B1 (anti-MSP1a). 1: MoAb ANAF16C1; 2: MoAb ANA22B1.

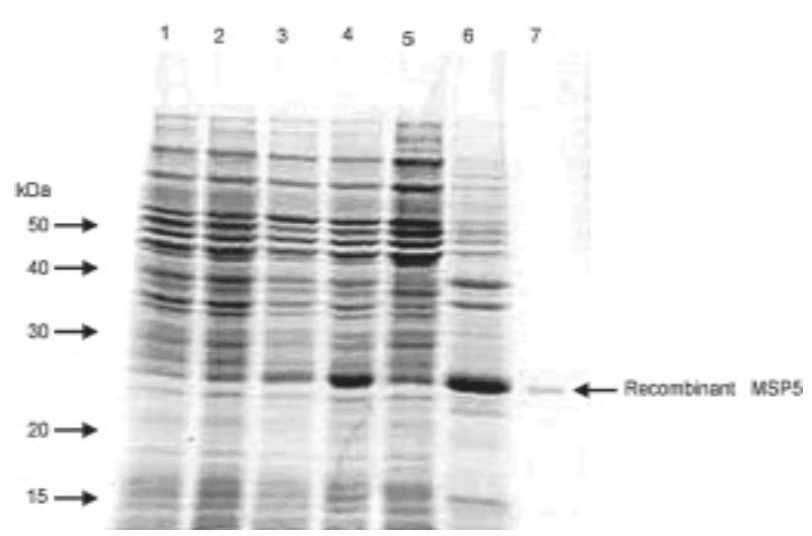

Fig. 2: Coomassie blue stained SDS-PAGE profile of Escherichia coli TOP 10 extracts expressing msp5 from a Brazilian isolate (Pernambuco-Zona da Mata) of Anaplasma marginale. Lanes - 1: extract of $E$. coli TOP10 transformed with pTrcHis-TOPO/mspla without induction with IPTG; $2: 2 \mathrm{~h}$ induction with IPTG; $3: 4 \mathrm{~h}$ induction with IPTG; 4: $6 \mathrm{~h}$ induction with IPTG; 5: soluble fraction; 6: insoluble fraction; 7: purified recombinant MSP5. 


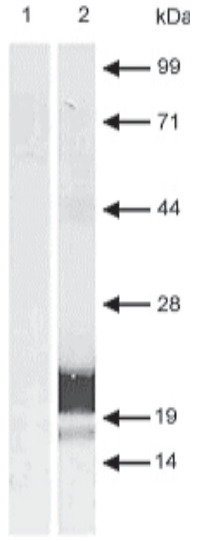

Fig. 3: Western blot of recombinant MSP5 from a Brazilian isolate (Pernambuco - Zona da Mata) of Anaplasma marginale and monoclonal antibody (MoAb) ANAF16C1 (anti-MSP5). 1: negative control (TOP 10 cells transformed with $p T r c H i s-T O P O / m s p 5$ without induction with IPTG; 2: TOP 10 cells transformed with pTrcHis$\mathrm{TOPO} / m s p 5$ induced with IPTG for $6 \mathrm{~h}$.

Performances of rMSP5 and IB ELISAs - After the initial standardization of rMSP5 and IB ELISAS, the performances of both tests were evaluated. The analysis of sensitivity and specificity from both tests in shown in Table I. There were no statistical differences neither in the sensitivities nor in the specificities between both tests $(\mathrm{P}>0.05)$.

Cross-reactions with Babesia sp. antibodies - No cross-reactions with $B$. bigemina antibodies were verified in both ELISAs. From the 20 serum samples positive for $B$. bovis antibodies in the IFAT, three $(15 \%)$ reacted with IB antigen and one (5\%) reacted with rMSP5 (Table II). Differences between both tests were not statistically significant $(\mathrm{P}>0.05)$.

Prevalence of A. marginale antibodies in an extensively-raised cattle herd - Prevalences of A. marginale antibodies in an extensively-raised cattle in Miranda county, Mato Grosso do Sul, by IB and rMSP5 ELISAs were 79.7 and $78.1 \%$, respectively (Table III). There were no statistical differences between both tests $(\mathrm{P}>0.05)$.

Evaluation of the ELISAs with sera from calves naturally-infected with A. marginale - The analysis of sera from 28 Holstein calves from a dairy farm, located on an endemic region for anaplasmosis, by IB-ELISA and rMSP5 ELISA showed a decrease in the mean ODs from day 7 to day 30, when the lowest ODs were recorded. From day 30, there was an increase in the ODs that peaked in the 360th day. This pattern was similar for both ELISAs, however the mean OD was always above the cut-off level in the IBELISA, whereas it reached the cut-off values in the days 15 and 30 in the rMSP5 ELISA (Fig. 4).

\section{TABLE II}

Cross-reactions with sera against Babesia bovis and B. bigemina in the ELISAs with recombinant MSP5 (rMSP5) and initial body (IB) ELISAs antigens of Anaplasma marginale

\begin{tabular}{lcc}
\hline $\begin{array}{l}\text { ELISA } \\
\text { antigen }\end{array}$ & $\begin{array}{c}\text { Reactions with } \\
\text { B. bigemina } \text { antibodies }\end{array}$ & $\begin{array}{c}\text { Reactions with } \\
\text { B. bovis antibodies }\end{array}$ \\
\hline IB & $0 / 20(0 \%)(a)$ & $3 / 20(15 \%)($ a) \\
rMSP5 & $0 / 20(0 \%)$ (a) & $1 / 20(5 \%)$ (a) \\
\hline
\end{tabular}

Rates with distinct letters in the same column indicate statistically significant differences by Fischer's exact test at the level of 5\%.

TABLE III

Prevalences of antibodies to Anaplasma marginale in cattle from Miranda county, Mato Grosso do Sul, by indirect ELISAs with recombinant MSP5 (rMSP5) and initial body (IB) antigens

\begin{tabular}{lccc}
\hline ELISA & $\begin{array}{c}\text { No. of sera } \\
\text { analyzed }\end{array}$ & $\begin{array}{c}\text { No. of } \\
\text { positive sera }\end{array}$ & $\%$ \\
\hline IB & 128 & 102 & 79.7 (a) \\
rMSP5 & 128 & 100 & 78.1 (a)
\end{tabular}

Rates with distinct letters in the same column indicate statistically significant differences by Chi-square test at the level of $5 \%$.

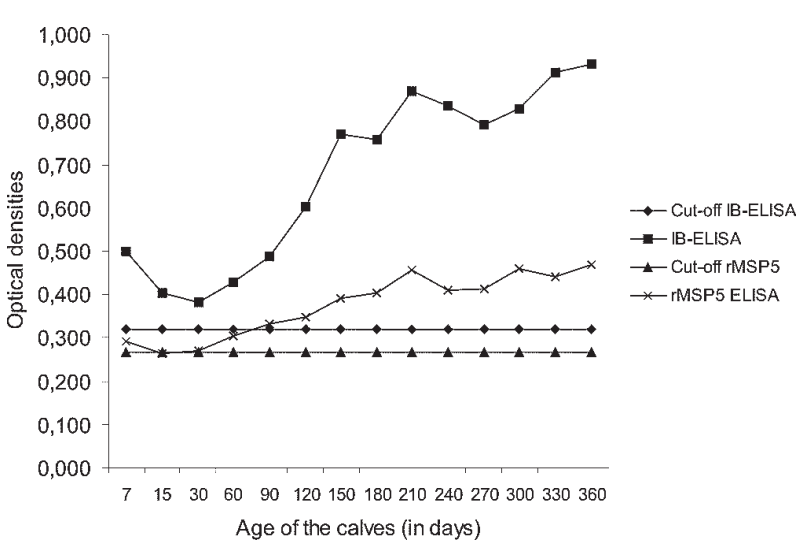

Fig. 4: levels of antibodies in dairy calves naturally-infected with Anaplasma marginale, evaluated by recombinant MSP5 and initial body antigens ELISAs.

TABLE I

Sensitivity and specificity from recombinant MSP5 (rMSP5) and initial body (IB) ELISAs in the detection of antibodies against Anaplasma marginale

\begin{tabular}{lccccrr}
\hline Antigen & $\begin{array}{c}\text { No. of IFAT }+ \\
\text { sera analyzed }\end{array}$ & $\begin{array}{c}\text { No. of ELISA } \\
\text { positive sera }\end{array}$ & Sensitivity & $\begin{array}{c}\text { No. of IFAT } \\
\text { sera analyzed }\end{array}$ & $\begin{array}{c}\text { No. of } \\
\text { positive sera }\end{array}$ & $\begin{array}{c}\text { Specificity } \\
\text { IB }\end{array}$ \\
rMSP5 & 57 & 56 & $98.2 \%$ (a) & 65 & 4 & $93.8 \%$ (a) \\
\hline
\end{tabular}

IFAT: indirect fluorescent antibody test; rates with distinct letters in the same column indicate statistically significant differences by Fischer's exact test at level of $5 \%$. 


\section{DISCUSSION}

The high degree of identity of MSP5 between the Brazilian and the American isolates of A. marginale at the DNA and protein levels is in accordance with the high level of conservation of this protein in Anaplasma spp. reported previously (Visser et al. 1992, Reyna-Bello et al. $1998)$. The $1.58 \%$ of non-identity (10/633 bp) was possibly due to mutations and/or to random errors during amplification with Taq DNA polimerase, which has a error rate of 0.2 to $2 \times 10^{-4}$ misincorporations per bp per cycle (Bracho et al. 1998).

The purification of A. marginale IB was partially achieved, as some contamination with erythrocyte proteins was detected in the SDS-PAGE. On the other hand, it was possible to purify rMSP5 by electroelution. The choice of this method was due to the failure in the purification of rMSP5 by affinity chromatography in agarose/ nickel columns.

The identity of rMSP5 was confirmed by Western blot with MoAb ANAF16C1 (Visser et al. 1992). This MoAb also recognized MSP5 in the IB preparation, along with ANA22B1, which recognized MSP1a, confirming the conservation of these proteins during the purification steps of the IB. The higher molecular mass of rMSP5 (22 kDa) when compared with the native protein was expected, as the vector $p$ TrcHis-TOPO encodes a 3-4 kDa N-terminal peptide, which includes a histidine tag.

In regards to the performances of rMSP5 and IB ELISAs, there were no statistical differences neither in the sensitivity nor in the specificities. Also, there was no statistically significant difference in the rates of crossreactions with $B$. bovis antibodies between the two ELISAs. This indicates that contamination of IB antigen with erythrocyte proteins did not influence the performance of the IB ELISA. Crude antigen ELISAs with erythrocyte proteins has been incriminated for false-positive reactions, as result of reaction with anti-erythrocyte antibodies in the sera (Barry et al. 1986). However, the crossed reactions probably occurred due to host immune reaction, because previously ELISA for detection of $A$. marginale antibodies displayed false positive reactions during acute phase of Babesia spp. infection (Madruga et al. 2000).Therefore, these ELISAs could be used for serological surveys in endemic areas.

The performances of IB and rMSP5 ELISAs in detecting antibodies against $A$. marginale in an extensively raised cattle herd of Mato Grosso do Sul, Brazil, were very similar and characterized the region as enzootically-stable. In such epidemiological conditions, the risk of outbreaks of anaplasmosis is low. However, the sampling of animals with varying ages may underestimate the true status, as there is the possibility that some animals were infected at ages above nine months, when they are less resistant to tick-borne diseases (Mahoney 1977).

The performances of IB and rMSP5 ELISAs in detecting antibodies against $A$. marginale in calves naturallyinfected with A. marginale in a dairy farm were very similar. In both tests, maternal antibodies reached the lowest levels by 15-30 days, with an increase in the mean ODs in both ELISAs thereafter, suggesting the development of active immunity against A.marginale. The ODs were higher in the IB ELISA, remaining above the cut-off level all the time, whereas in the rMSP5 ELISA, the ODs reached the cut-off level on days 15 and 30. Results showed that all calves were seropositive by one-year old, characterizing a situation of enzootic stability. Despite the fact that calves were kept in individual stalls from day 2 up to four months of age, they were infected, since the ELISA ODs increased constantly. They were probably infected by ticks during the first day of life, when they remained with their mothers, or by blood-sucking diptera.

The similar performances of the ELISAs suggest that both tests can be used in epidemiological surveys for detection of antibodies to A. marginale in cattle. However, the antigen production and the standardization of each batch of antigen seems to be easier in the rMSP5 ELISA.

\section{REFERENCES}

Ajayi SA, Wilson AJ, Campbell RS 1978. Experimental bovine anaplasmosis: clinico-pathological and nutritional studies. Res Vet Sci 25: 76-81.

Andrade GM, Machado RZ, Vidotto MC, Vidotto O 2004. Immunization of bovines using DNA vaccine (pcDNA 3.1/ MSP1B) prepared from Jaboticabal strain of Anaplasma marginale. Ann NY Acad Sc 1026: 257-267.

Barros SL, Madruga CR, Araújo FR, Menk CF, Almeida de MAO, Melo EPS, Kessler RH 2005. Serological survey of Babesia bovis, Babesia bigemina, and Anaplasma marginale. antibodies in cattle from semi-arid region of the state of Bahia, Brazil, by enzyme-linked immunosorbent assays. Mem Inst Oswaldo Cruz 100: 513-517.

Barry DN, Parker RJ, De Vos AJ, Dunster P, Rodwell BJ 1986. A microplate enzyme-linked immunosorbent assay measuring antibody to Anaplasma maiginale in cattle serum. Aust Vet J 63: 76-79.

Bracho MA, Moya A, Barrio E 1998. Contribution of Taq polymerase-induced errors to the estimation of RNA virus diversity. J Gen Virol 79: 2921-2928.

Centro Pan-Americano de Zoonoses 1979. Procedimientos para Estudios de Prevalencia por Muestreo, Ramos Mejia, Buenos Aires, 35 pp.

Correa WM, Correa CN, Gottschalk AF 1978. Bovine abortion associated with Anaplasma marginale. Can J Comp Med 42: 227-228.

Dumler JS, Barbet AF, Bekker CP, Dasch GA, Palmer GH, Ray SC, Rikihisa Y, Rurangirwa FR 2001. Reorganization of genera in the families Rickettsiaceae and Anaplasmataceae in the order Rickettsiales: unification of some species of Ehrlichia with Anaplasma, Cowdria with Ehrlichia and Ehrlichia with Neorickettsia, descriptions of six new species combinations and designation of Ehrlichia equi and 'HGE agent' as subjective synonyms of Ehrlichia phagocytophila. Int J Syst Evol Microbiol 51: 2145-2165.

Kano FS, Vidotto O, Pacheco RC, Vidotto MC 2002. Antigenic characterization of Anaplasma marginale isolates from different regions of Brazil. Vet Microbiol 87: 131-138.

Knowles D, Torioni de Echaide S, Palmer G, McGuire T, Stiller D, McElwain T 1996. Antibody against an Anaplasma marginale MSP5 epitope common to tick and erythrocyte 
stages identifies persistently infected cattle. J Clin Microbiol 34: $2225-2230$.

Madruga CR, Marques APC, Leal CRB, Carvalho CME, Araújo FR, Kessler RH 2000. Evaluation of an enzyme-linked immunosorbent assay to detection of antibodies against Anaplasma marginale. Pesq Vet Bras 20: 109-112.

Mahoney DF 1977. The diagnosis of babesiosis in Australia. In EA Wells Workshop on Hemoparasites (Anaplasmosis and Babesiosis), CIAT, Cali, p. 49-62.

McGuire TC, Davis WC, Brassfield AL, McElwain TF, Palmer GH 1991. Identification of Anaplasma marginale long-term carrier cattle by detection of serum antibody to isolated MSP-3. J Clin Microbiol 29: 788-793.

Ndung'u LW, Aguirre C, Rurangirwa FR, McElwain TF, McGuire TC, Knowles DP, Palmer GH 1995. Detection of Anaplasma ovis infection in goats by major surface protein 5 competitive inhibition enzyme-linked immunosorbent assay. J Clin Microbiol 33: 675-679.

Neophytou PI, Ozegbe P, Healey D, Quartey-Papafio R, Cooke A, Hutton JC 1996. Development of a procedure for the direct cloning of T-cell epitopes using bacterial expression systems. J Immunol Methods 196: 63-72.

Oberle SM, Palmer GH, Barbet AF, McGuire TC 1988. Molecular size variations in an immunoprotective protein complex among isolates of Anaplasma marginale. Infect Immun 56: $1567-1573$.

Oliveira JB, Madruga CR, Schenk MA, Kessler RH, Miguita M, Araujo FR 2003. Antigenic characterization of Brazilian isolates of Anaplasma marginale. Mem Inst Oswaldo Cruz, 98: 395-400.

Palmer GH, McGuire TC 1984. Immune serum against Ana- plasma marginale initial bodies neutralizes infectivity for cattle. J Immunol 133: 1010-1015.

Palmer GH, Barbet AF, Kuttler KL, McGuire TC 1986. Detection of an Anaplasma marginale common surface protein present in all stages of infection. J Clin Microbiol 23: 10781083.

Palmer GH, Barbet AF, Musoke AJ, Katende JM, Rurangirwa F, Shkap V, Pipano E, Davis WC, McGuire TC 1988. Recognition of conserved surface protein epitopes on Anaplasma centrale and Anaplasma marginale isolates from Israel, Kenya and the United States. Int J Parasitol 18: $33-$ 38.

Reyna-Bello A, Cloeckaert A, Vizcaino N, Gonzatti MI, Aso PM, Dubray G, Zygmunt MS 1998. Evaluation of an enzyme-linked immunosorbent assay using recombinant major surface protein 5 for serological diagnosis of bovine anaplasmosis in Venezuela. Clin Diagn Lab Immunol 5: 259262.

Riding G, Hope M, Waltisbuhl D, Willadsen P 2003. Identification of novel protective antigens from Anaplasma marginale. Vaccine 21: 1874-1883.

Torioni de Echaide S, Knowles DP, McGuire TC, Palmer GH, Suarez CE, McElwain TF 1998. Detection of cattle naturally infected with Anaplasma marginale in a region of endemicity by nested PCR and a competitive enzyme-linked immunosorbent assay using recombinant major surface protein 5. J Clin Microbiol 36: 777-782.

Tuszynski GP, Warren L 1975. Removal of sodium dodecyl sulfate from proteins. Anal Biochem 67: 55-65.

Visser ES, McGuire TC, Palmer GH, Davis WC, Shkap V, Pipano E, Knowles Jr DP 1992. The Anaplasma marginale msp5 gene encodes a 19-kilodalton protein conserved in all recognized Anaplasma species. Infect Immun 60: 5139-5144. 